\title{
KIss LóRÁND*
}

\section{FALKÉPEK KUTATÁSA ÉS HELYREÁLLÍTÁSA AZ ERDÉLYI SZÁSZ EVANGÉLIKUS TEMPLOMOKBAN}

\author{
Kulcsszavak: Darlac, erdélyi szász templomok, középkori falképfestészet, Küküllőkörös, \\ Somogyom, Szászivánfalva, Szászzsolna
}

A jelen beszámoló egy öt évvel ezelőtt elkezdett kutatási program részeredményeinek a vázlatos bemutatására törekszik.

E kutatás rendszerezetté, programszerűvé tételének ötlete öt-hat évvel ezelőtt kezdett el körvonalazódni. Indítéka az volt, hogy az erdélyi szász templomok falképegyüttesei elsősorban a tulajdonosok részéról eddig nem élveztek különösebb figyelmet. A szász múvészettörténet-írás elsősorban a gótikus táblaképekre, bútorzatra, illetve az építészeti elemekre, múrészletekre koncentrált, s néhány kiemelkedő együttest (Almakerék, segesvári Hegyi-templom, brassói Fekete-templom stb.) kivéve a falképeket mellőzte. E templomok falképei a nagy ismeretlent jelentették és jelentik ma is a múvészettörténészek és a restaurátorok számára, annak ellenére, hogy a falfestmények területén is legalább olyan jelentős emlékek felbukkanása várható, mint az építészet, táblaképfestészet területén.

Kutatásunk, mely asztalosmunkák felmérésével egy idôben folyik eleinte elsősorban a medgyesi egyházkör templomait érintette, de az elmúlt évek folyamán kiterjedt a segesvári, brassói, besztercei egyházkörökre is. Az érintett templomok egy részében európai uniós pályázat keretében végzett helyreállitás vagy felújitás adott lehetőséget a kutatásra, más esetben a vizsgálat a tulajdonos felkérésére, személyes kezdeményezésre, önerőből, vagy civil támogatásból történt.

Természetes, hogy egy-egy templom falkutatása nem szolgáltatott teljes és kimerítő információt, de legfontosabb lappangó értékeit mindenképpen azonosítani lehetett. Ugyanakkor az ilyen kutatás számos új ismerettel egészíti ki az adott együttes építéstörténetét. Eddig 38 evangélikus templom kutatása történt meg. A kutatás eredményeiről egy-egy képekkel dokumentált restaurátori beszámoló készült. Minden objektumoknál vakolat- és pigmensmintákat vettünk, hogy magalapozzunk egy majdani történeti pigmens- és vakolat-inventáriumot.

Az összegyújtött adatokat, szakmai beszámolókat, a kutatás eredményeit egy honlapra (www.monumenta.ro) töltjük fel, mindenki számára elérhetővé téve azokat.

* Kiss Lóránd (1973), festő-restaurátor, festészeti diplomát a kolozsvári Ioan Andreescu Múvészeti Egyetemen szerzett 1996-ban. Fontosabb munkái: az alcinai evangélikus templom falképeinek restaurálása (2008-2010), a medgyesi evangélikus erődtemplom Mária-tornya kápolnájában található falképek restaurálása (Pál Péterrel, 2008), a csíkmenasági római katolikus templom szentélye falképeinek restaurálása (Pál Péterrel, 2009-2011), a bögözi református templom falképeinek restaurálása (Pál Péterrel, 2011-2012). 
A továbbiakban néhány példával szeretnénk felhívni a figyelmet arra, hogy milyen menynyiségű és minőségű, nagyrészt teljesen ismeretlen emlékanyaggal állunk szemben.

A szászivánfalvi evangélikus templom hajójában és szentélyében mintegy 120-140 négyzetméter középkori falképfelület található vakolat és meszelésrétegek alatt (1. kép). A szakirodalom a templom falképeinek létezéséről csak érintőlegesen emlékezik meg. A nagyméretű hajó északi fala teljes mértékben ki van festve, a falfestmények $140 \mathrm{~cm}$ magasságtól a menynyezetig takarják a falfelületet. Három egymás alatti regiszter, s a legalsó regiszter alatt egy lábazati díszítőfestés is látható. A kutatóablakok alapján a legfelső regiszter a Szent Lászlólegenda képciklusait ábrázolja (4-5. kép). A két alsó regiszterben szintén szentek alakjai láthatók, de a kutatóablakok egyelőre nem szolgálnak elegendő információval azonosításukhoz. A diadalív hajó felőli oldala szintén teljes mértékben ki van festve, az északi karzat szomszédságában pedig az Utolsó ítélet jelenete figyelhető meg (2-3. kép). Hajdan a szentély teljes felületét is falképek borították, töredékeik a boltozaton és a szentélyzáródásban maradtak meg. A falfestmények stilisztikai és technikai jellemzői alapján kijelenthetjük, hogy a hajó, a diadalív és a szentély falképei egységes kifestés eredményei, amelyek stilisztikailag az almakeréki falképekkel hozhatók szoros összefüggésbe (6. kép). A szászivánfalvi és almakeréki alakok fej- és arcmegoldásait összevetve felmerül az azonos mester vagy azonos múhely lehetôsége.

A Beszterce melletti Szászzsolna evangélikus temploma mintegy 15 éve lett rommá. A hajó boltozata és falainak egy része beomlott, a szentély gótikus bordás keresztboltozata még áll (7-8. kép). A szentély északi és északkeleti oldalán a málló vakolatok alól középkori falképek váltak láthatóvá (hozzávetőleg $20 \mathrm{~m}^{2}$-nyi festett felület). Néhány éve a szentély falképeinek egy részét (a jobb állapotban megmaradt, látványosabb figurák fejeit) leválasztották, s a besztercei múzeumban kiállították, a „lefejezett” jeleneteket sorsukra hagyva (9. kép). A falakon maradt festményeken semmilyen állagmegőrzés nem történt. Ez a példa hű érzékeltetője az erdélyi szász kulturális örökséggel kapcsolatosan kialakult állapotoknak.

A Medgyes melletti Darlac evangélikus templomát a szakirodalom a külső falképei révén ismeri (10. kép). A szentély külső falfelületeit ugyanis a Passió jelenetei, illetve egy nagyméretű Szent Kristóf-ábrázolás díszíti. Belső falképeiről mindeddig egy, az ülőfülkében feltárt kisebb részlet árulkodott. A kutatás során kiderült, hogy a teljes szentélybelsőt, beleértve a diadalív bélletét és a boltozatot is középkori falképek díszítik. E falképek azonos stílusjegyeket mutatnak a külső falképekkel, valószínű, hogy készítőjük azonos mester vagy múhely lehetett. A szentély déli falán Szent Katalin, illetve Szent Ilona legendái láthatók (11. kép), az ülőfülkében Szent István és László királyok álló alakjai, a szentély északi falán pedig egy nagyméretű Utolsó ítélet látható (12-14. kép). A falképek stílusa és készítéstechnikája egyértelmúen arról árulkodik, hogy készítőjük a bizánci kultúrkörben formálódott.

Medgyes és Erzsébetváros között, a Nagy-Küküllő egyik jobb oldali mellékvölgyében található Somogyom. A somogyomi evangélikus templom falképei egy javítás során kerültek felszínre, miközben a templomot időlegesen a falu görög-keleti felekezetű közössége használta (15. kép). A hajó északi oldalán akkor két egymás alatti jelenetet szabadon hagytak, a többit visszameszelték. A falkutatás után nyilvánvalóvá vált hogy a teljes északi hajófal a járószinttől a mennyezetig ki van festve. Három egymás alatti regiszterben, Szent Katalin legendája, Szent Péter keresztre feszítése és az Utolsó ítélet két jelenete (a lelkeket mérő Szent Mihály arkangyal és a Köpönyeges Mária) azonosítható (16-17. kép). A teljes szentélybelsőt, beleértve annak boltozatát és a diadalívet késő gótikus jellegű figurális kifestés díszíti. A déli ülőfül- 
kében Szent István és Szent László királyok térdeplő alakjai ismerhetők fel. A templombelső teljes falképes felülete mintegy 250-280 négyzetméterre becsülhető.

A szentély külső déli falán egy nagyrészt lepusztult, nagyméretű Szent Kristóf, keleti oldalán egy Fájdalmas Krisztus ábrázolás, az északin egy mára felismerhetetlen jelenet látható. E három külső jelenet készítéstechnikai és az értékelhető stilisztikai elemek alapján a darlaci bizánci jellegű falfestményekkel hozható összefüggésbe.

A Darlactól 5 km-re északi irányban fekvő Küküllőkőrös evangélikus erődtemplomában is egy, az 1980-as években végzett belső felújítás-meszelés hozta felszínre a középkori falképeket. A 15. század második felében készült falképek a szentély teljes északi oldalát beborítják, három, egymás alatti regiszterben. A középső regiszter sekrestyeajtó fölötti részén Krisztus Pilátus előtt-jelenet látható. A vegyes, freskó-szekkó technikával festett falkép festékrétegének egy része elpusztult, de a freskó technikával festett arcképek viszonylag épen fennmaradtak. Ezek egy kivételes képességű, tapasztalt, kitűnő rajztudású festőről árulkodnak. A plasztikusan, anatómiai hitelességgel megformált arcok mind arra utalnak hogy festőjük valamelyik festő-képíró céh keretében szerezhette meg tudását. A szentély északi falán hozzávetôleg $62 \mathrm{~m}^{2}$ falképes felület maradt fenn.

Összegzésképpen, e négy kiragadott példa jól szemlélteti azt, hogy milyen meglepetéseket tartogat az alig ismert szász falképes emlékek. Az eddig kutatott anyag gazdagságát a száraz statisztikai adatok is jelzik: a 38 kutatott templomból 34-ben találtunk középkori falképet, s további két templomban későbbi feliratokat, díszítéseket.

Az általunk programnak titulált kutatássorozat, adat- és információgyújtés nehézkesen haladt és halad előre, híjával minden állami vagy bármilyen jellegű más állandó támogatásnak. Megteremtettünk egy olyan on-line felületet, amelyen ezt az információhalmazt többé-kevésbé rendezetten, bárki számára elérhetővé tudjuk tenni. Ennek a felületnek a ki- és felépítésében erdélyi magáncégek, támogatók voltak a segítségünkre. Jelenleg kb. 120 objektumról vannak adatok feltöltve (ennek az anyagnak az evangélikus templomok természetesen csak egy szeletét jelentik).

Az elsorolt nehézségek ellenére végszóként ki kell mondanunk, hogy a fent vázolt program nem elég koherens, nem biztosított folyamatossága, mégis, tekintettel az adott objektumok és műalkotások jelentőségére, érdemes folytatni. Többek között azért, mert sok esetben vissza nem térő alkalmakról és lehetôségekrôl, nap mint nap pusztuló értékekrôl van szó. A felfedezett (részben feltárt) falképek művészettörténeti és ikonográfiai értelmezése, beillesztése az erdélyi művészet történetébe egy távolabbi feladatot jelent. Meggyőződésünk, hogy a kutatások révén felszínre került ismeretanyag által az erdélyi középkori falképekről sokkal teljesebb, összefüggéseiben gazdagabb képet alkothatunk. 


\title{
RESEARCH AND CONSERVATION OF MURALS IN LUTHERAN CHURCHES OF MEDIAŞ ARCHDEACONRY
}

\author{
Keywords: saxon churches from Transylvania, Curciu, Dârlos, Ighişul Nou, Jelna, \\ medieval murals, Șmig
}

The study presents a five years old project, which initially included churches of Mediaş archdeaconry, later included Lutheran churches of the other administrative areas too.

The project takes aim the research of murals of the denominated area. We would like to stress cause these churches are containing murals with the same artistic value than architectural or like the winged altars, although they are unknown to the specialists too (with some exceptions: Mălâncrav - Malmkrog, Church on the Hill from Sighişoara - Schässburg).

The main proposal of the project was the localization and delimitation of the murals. To the present was made the research of 38 Lutheran churches, and a great number of murals discovered. A good example is the mural of the Lutheran church of Ighişul Nou (Eibesdorf), which painter has worked in the choir of the church of Mălâncrav too. At Ighişul Nou was discovered around 220 mp of mural, at Cur$\mathrm{ciu}$ (Kirtsch) around $70 \mathrm{mp}$, and at Şmig (Schmiegen) around $210 \mathrm{mp}$ form the $15^{\text {th }}$ Century. The results of the researches are published at the site www.monumenta.ro.

\section{CERCETAREA ŞI CONSERVAREA PICTURILOR MURALE DIN BISERICILE EVANGHELICE ALE PROTOPOPIATULUI MEDIAŞULUI}

\section{Cuvinte-cheie: biserici săsești din Transilvania, Curciu, Dârlos, Ighișul Nou, Jelna, pictură murală medievală, Șmig}

Lucrarea de față încearcă să promoveze în rândul specialiștilor un proiect demarat cu cinci ani în urmă, care prevedea inițial cercetarea picturilor murale în bisericile din Protopopiatul Evanghelic al Mediașului, ulterior fiind incluse biserici evanghelice și din alte zone administrative. Trebuie să subliniem că deși, picturile murale reprezintă valori artistice istorice tot atât de prețioase ca și arhitectura sau altarele poliptice din lăcașurile cercetate, cu excepția câtorva exemple - Mălâncrav, Biserica din Deal de la Sighișoara - aceste picturi nu sunt cunoscute nici măcar de către specialiști (istorici de artă sau restauratori).

Proiectul a propus cercetarea acestor biserici pentru localizarea și delimitarea picturilor murale. Până în prezent s-a efectuat cercetarea a 38 de biserici evanghelice. În urma cercetărilor au fost descoperite numeroase ansambluri de picturi murale, cum ar fi spre exemplu picturile murale din biserica evanghelică Ighișul Nou, ale căror pictor a lucrat și în absida bisericii din Mălâncrav. La Ighișul Nou s-au descoperit cca 220 mp. de pictură murală, la Curciu cca 70 mp., iar la Șmig cca 210 de mp. datând din secolul al XV-lea. Rezultatele cercetărilor sunt publicate și pe site-ul www.monumenta.ro.

\section{KÉPJEGYZÉK / LIST OF ILLUSTRATIONS / LISTA ILUSTRAṬIILOR}

1. A szászivánfalvi (Eibesdorf) evangélikus templom délnyugat felől / The Lutheran church of Ighișul Nou (Eibesdorf) from south-west / Biserica evanghelică din Ighișul Nou (Eibesdorf) dinspre sud-vest 
2. A diadalív északi falpillére a hajó felól: Utolsó ítélet-jelenet részlete / The northern pillar of the triumphal arch from the nave: detail with the Last Judgment / Stâlpul nordic al arcului de triumf dinspre navă: detaliul scenei Judecății de Apoi

3. A hajó pillére a diadalív felól: Utolsó ítélet, harsonás angyalok / The northern pillar of the triumphal arch from the nave: Angels with trumpet / Stâlpul nordic al arcului de triumf dinspre navă: îngeri cu trompetă

4. A kun lefejezése a Szent László-legendából / The Beheading of the Cuman form the legend of king Saint Ladislaus / Decapitarea cumanului din legenda regelui Sfântul Ladislau

5. A kun arca a lefejezés jelenetéból / The face of the Cuman from the beheading-scene / Fața cumanului din scena decapitării

6. Férfifej a szentély keleti falán / Male face on the eastern wall of the choir / Cap de bărbat pe peretele estic al corului

7. A szászzsolnai (Senndorf) evangélikus templom romjai / The ruins of Lutheran church of Jelna (Senndorf) / Ruinele bisericii evanghelice din Jelna (Senndorf)

8. Az evangélikus templom belseje / Interior of the Lutheran church / Interiorul bisericii evanghelice

9. Figurális falképtöredék a szentély északi falán / Figurative mural fragment on the northern wall of the choir / Fragment de pictură murală figurativă pe peretele nordic al corului

10. A darlaci (Durles) evangélkus templom délkelet felől / The Lutheran church of Dârlos (Durles), from south-east / Biserica evanghelică de la Dârlos (Durles) dinspre sud-est

11. Szent Ilona halála a szentély déli falán / The death of Saint Helene on the southern wall of the choir / Moartea Sfintei Elena pe peretele sudic al corului

12. Utolsó ítélet jelenete a szentély északi falán / The Last Judgment on the northern wall of the choir / Scena Judecății de Apoi pe peretele nordic al corului

13. Krisztus arca az Utolsó ítélet jelenetén / Jesus' face from the Last Judgment / Fața lui Isus din scena Judecății de Apoi

14. Jakab és Pál apostolok alakjai az Utolsó Ítélet jelenetén / Apostles James and Paul from the Last Judgment-scene / Figurile apostolilor Iacob și Pavel din scena Judecății de Apoi

15. A somogyomi (Schmiegen) evangélikus templom délkelet felől / The Lutheran church of Șmig (Schmiegen), from south-east / Biserica evanghelică din Șmig (Schmiegen) dinspre sud-est

16. A hajó északi fala a feltárt falkép-részletekkel / The northern wall of the nave with the revealed mural fragments / Peretele nordic al navei cu fragmentele de pictură murală dezvelite

17. A hajó északi fala, alsó regiszter: Utolsó ítélet jelenetei / Northern wall of the nave, lower register: scenes of the Last Judgment / Peretele nordic al navei, registrul de jos: scenele Judecății de Apoi

18. A Szent Katalin-legenda felső regisztere / Upper register of the legend of Saint Catherine / Registrul superior al legendei Sfintei Ecaterina

19. A küküllőkörösi (Kirtsch) evangélikus templom. A szentély északi fala, részlet a Krisztus Pilátus előtt c. jelenetből / The Lutheran church of Curciu (Kirtsch). The northern wall of the choir, detail of the scene Jesus before Pilate / Biserica evanghelică din Curciu (Kirtsch). Peretele nordic al corului, detaliul scenei Isus în faţa lui Pilat

20. Férfiarc a szentély északi falán / Male face on the northern wall of the choir / Cap de bărbat pe peretele nordic al corului

21. Férfiarc a szentély északi falán / Male face on the northern wall of the choir / Cap de bărbat pe peretele nordic al corului 


\section{KISS LÓRÁND}
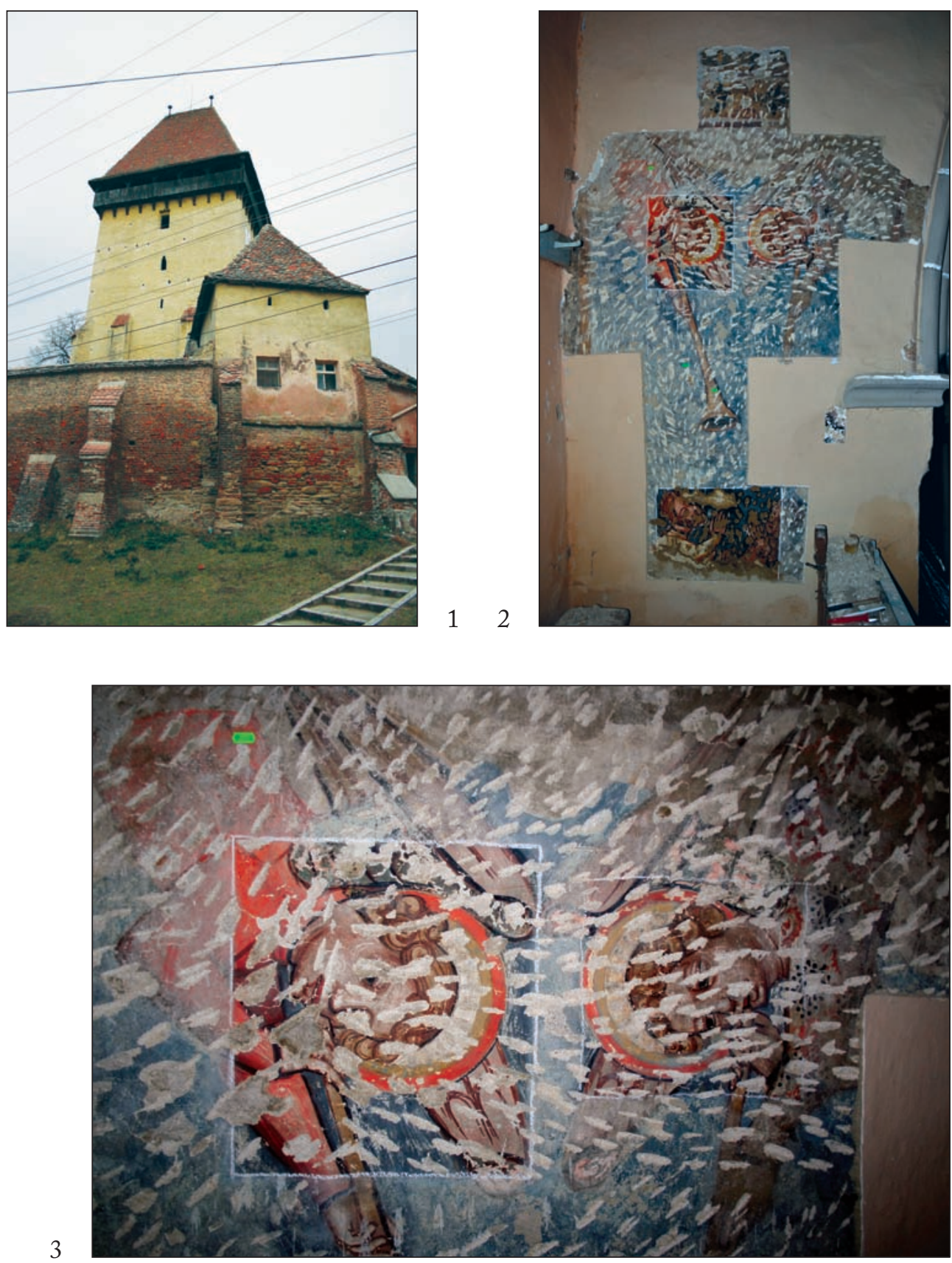
Kiss Ló r ánd

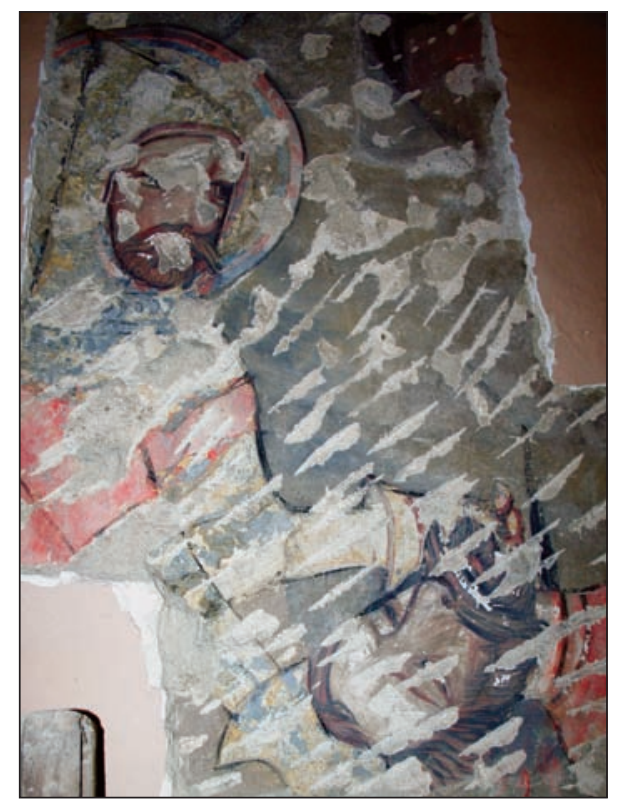

4

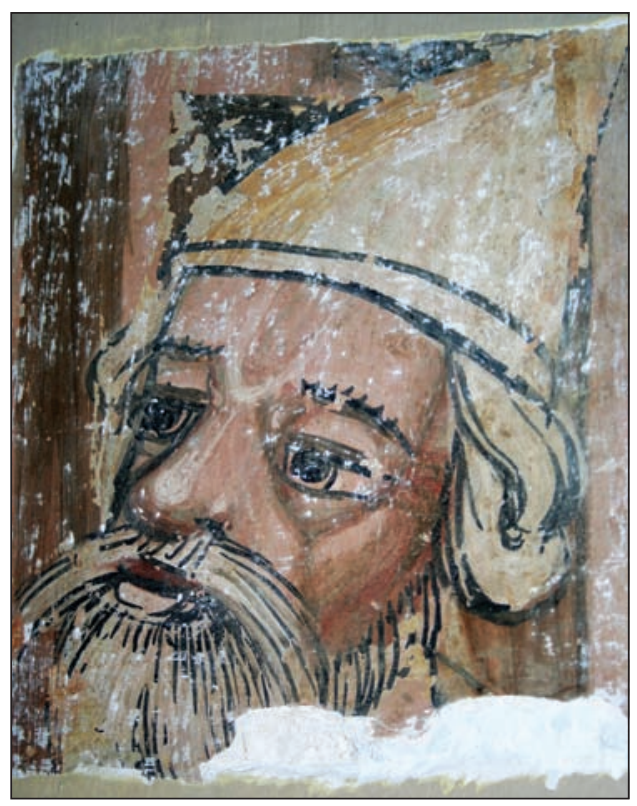

6

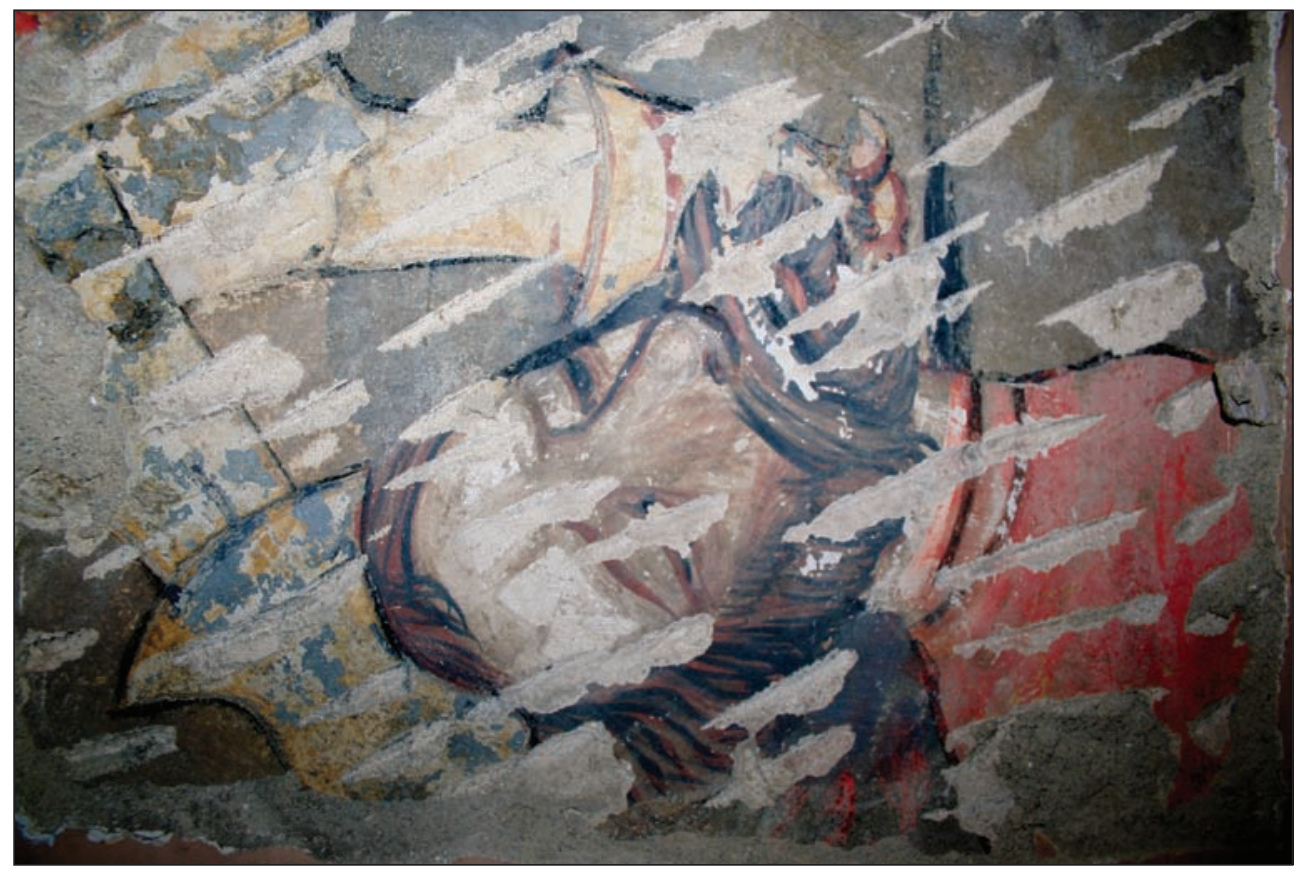


FALKÉPEK KUTATÁSA ÉS HELYREÁLLÍTÁSA

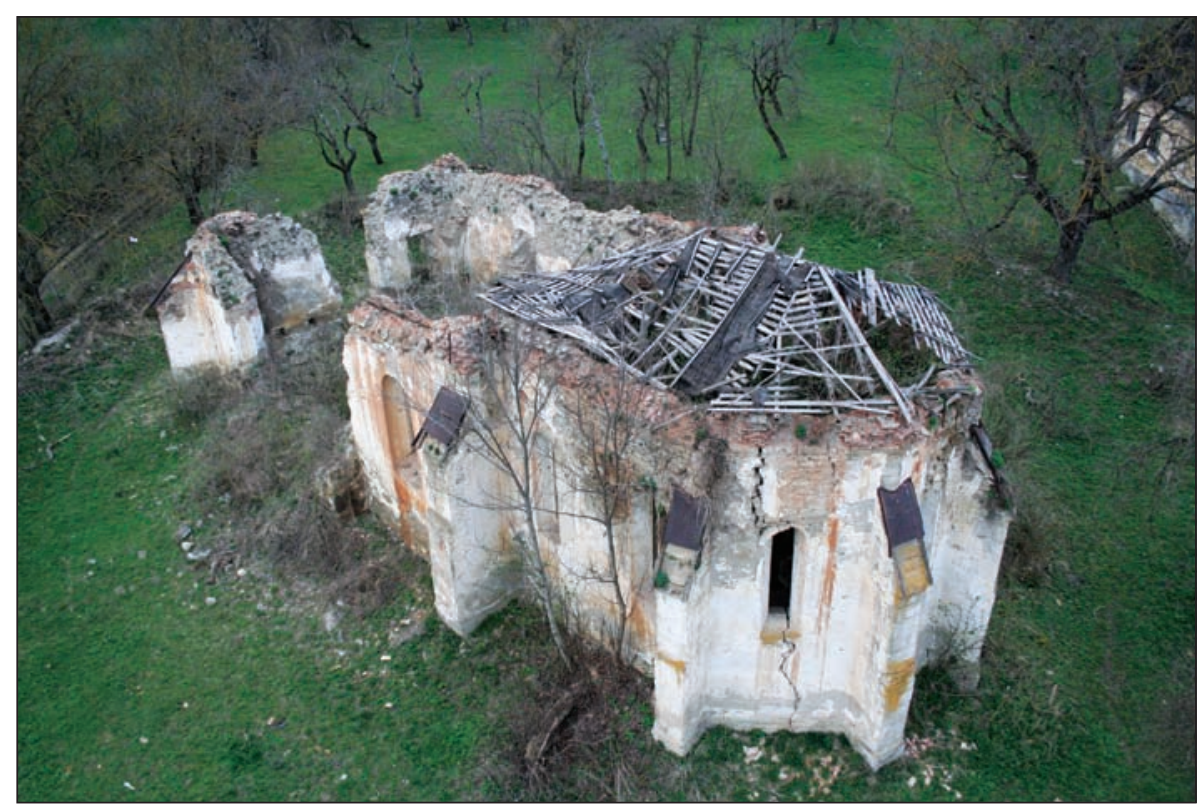

7

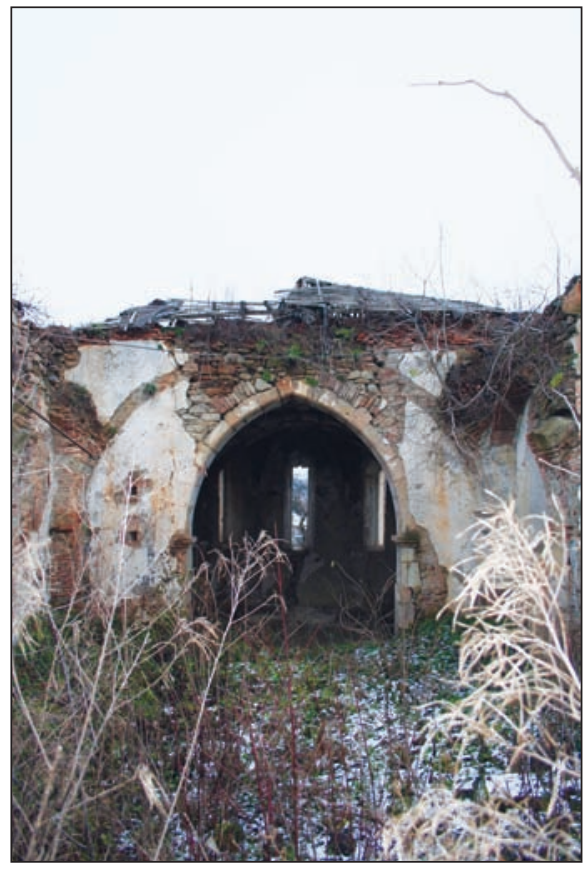

8

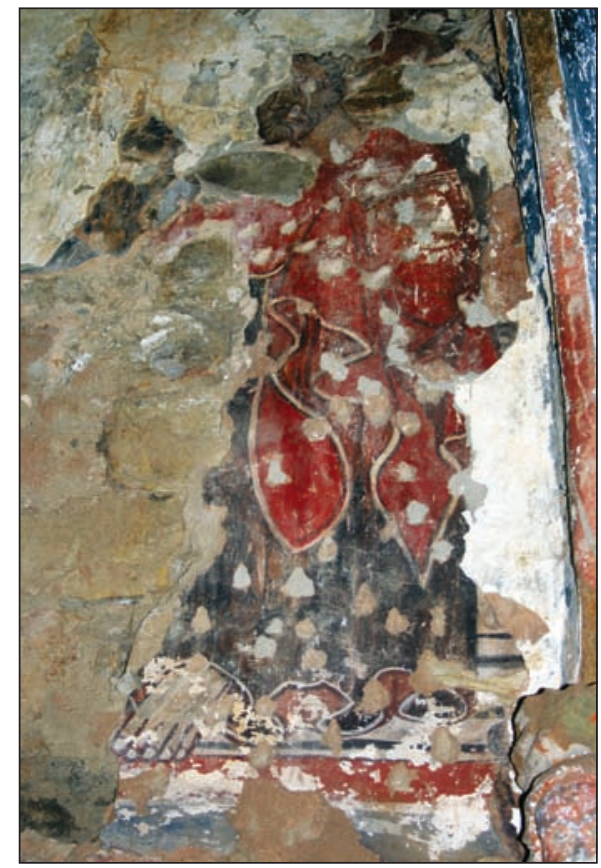

9 
Kiss Ló r ánd
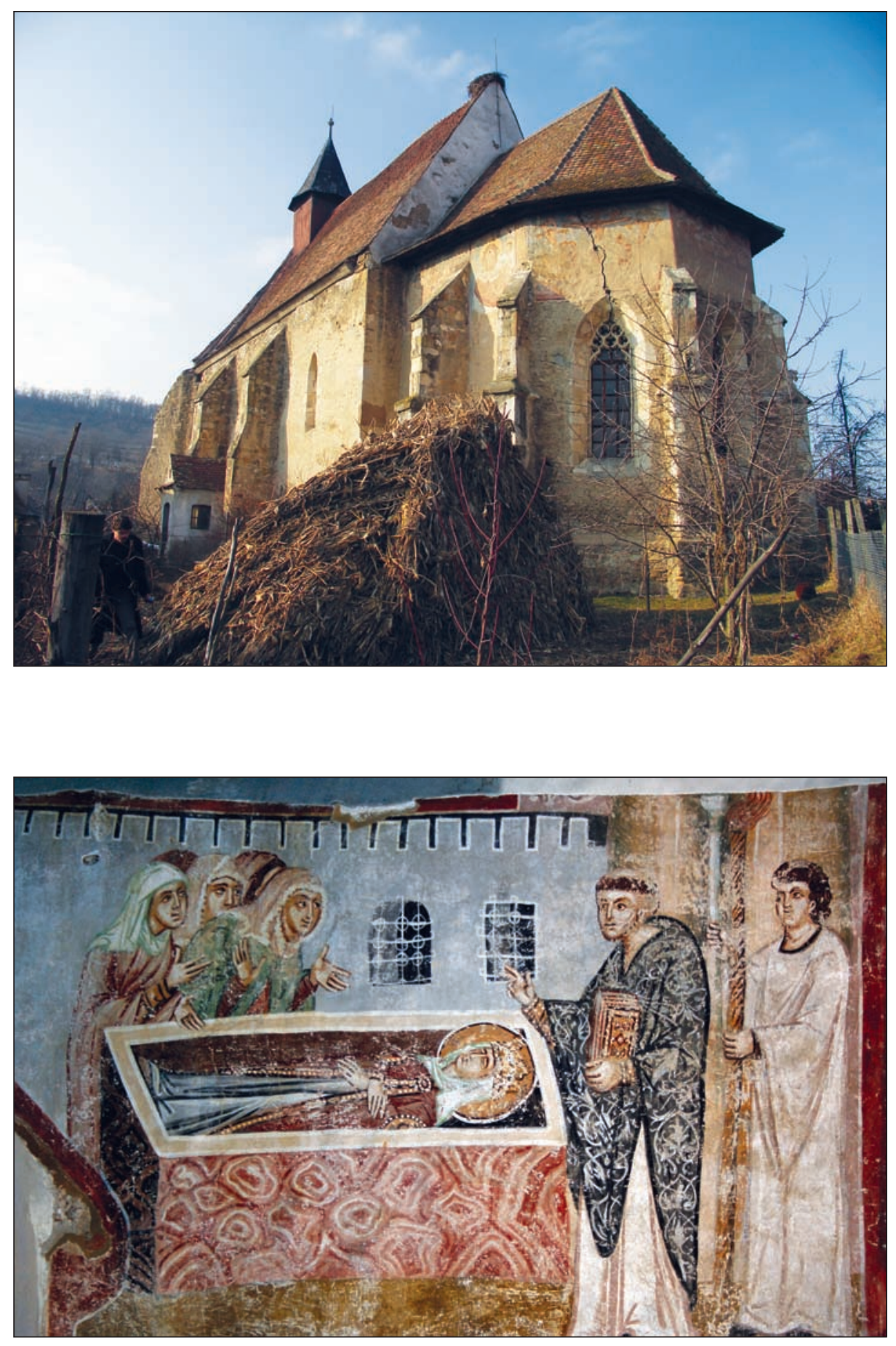


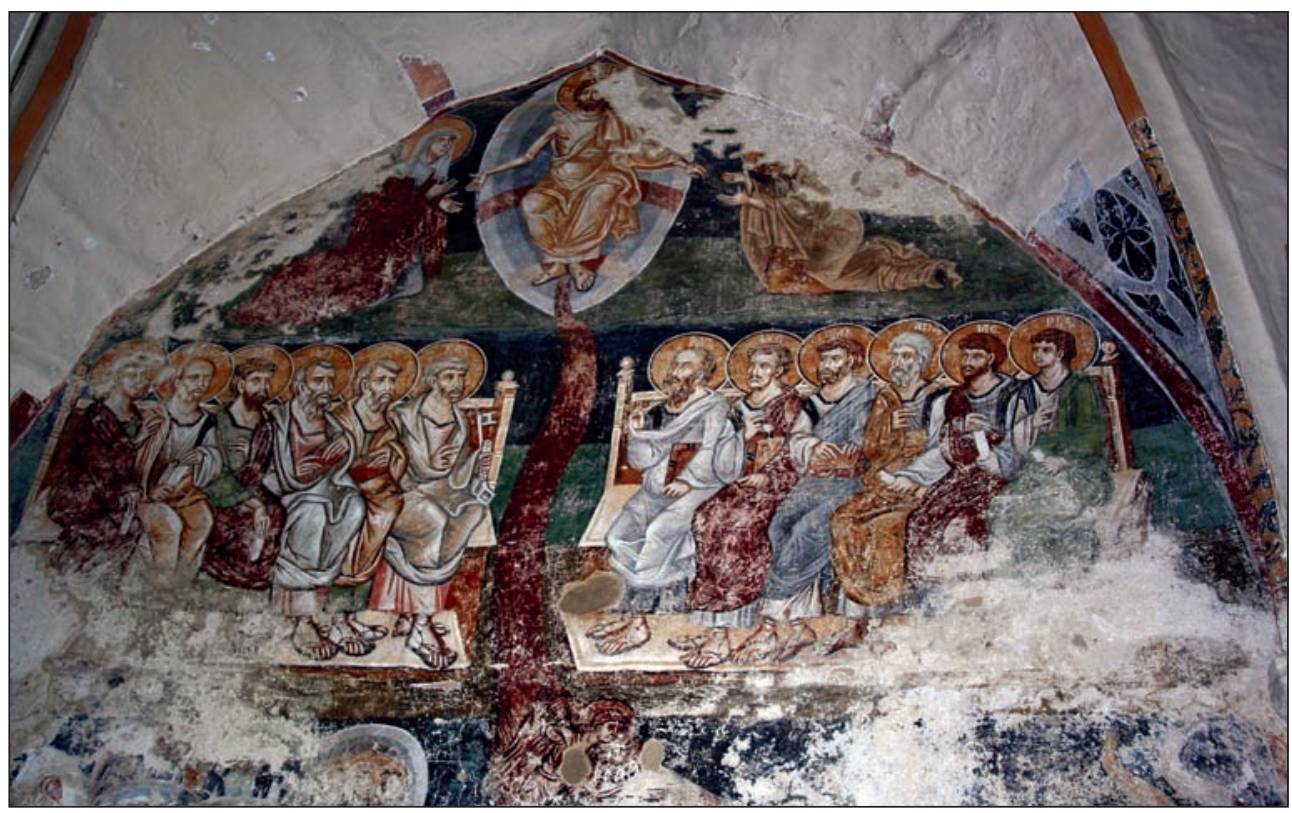

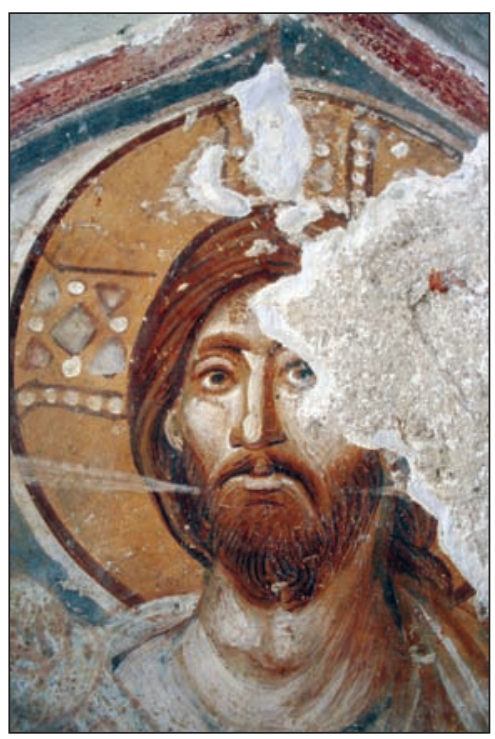

13

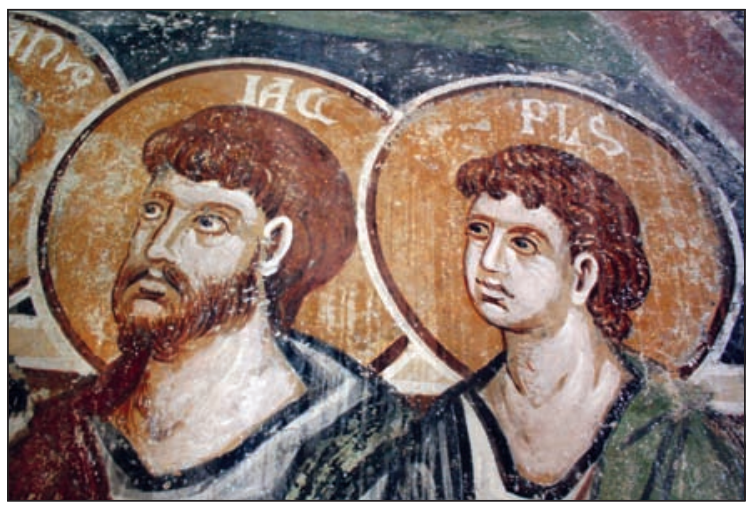

14 
Kiss Ló r ánd
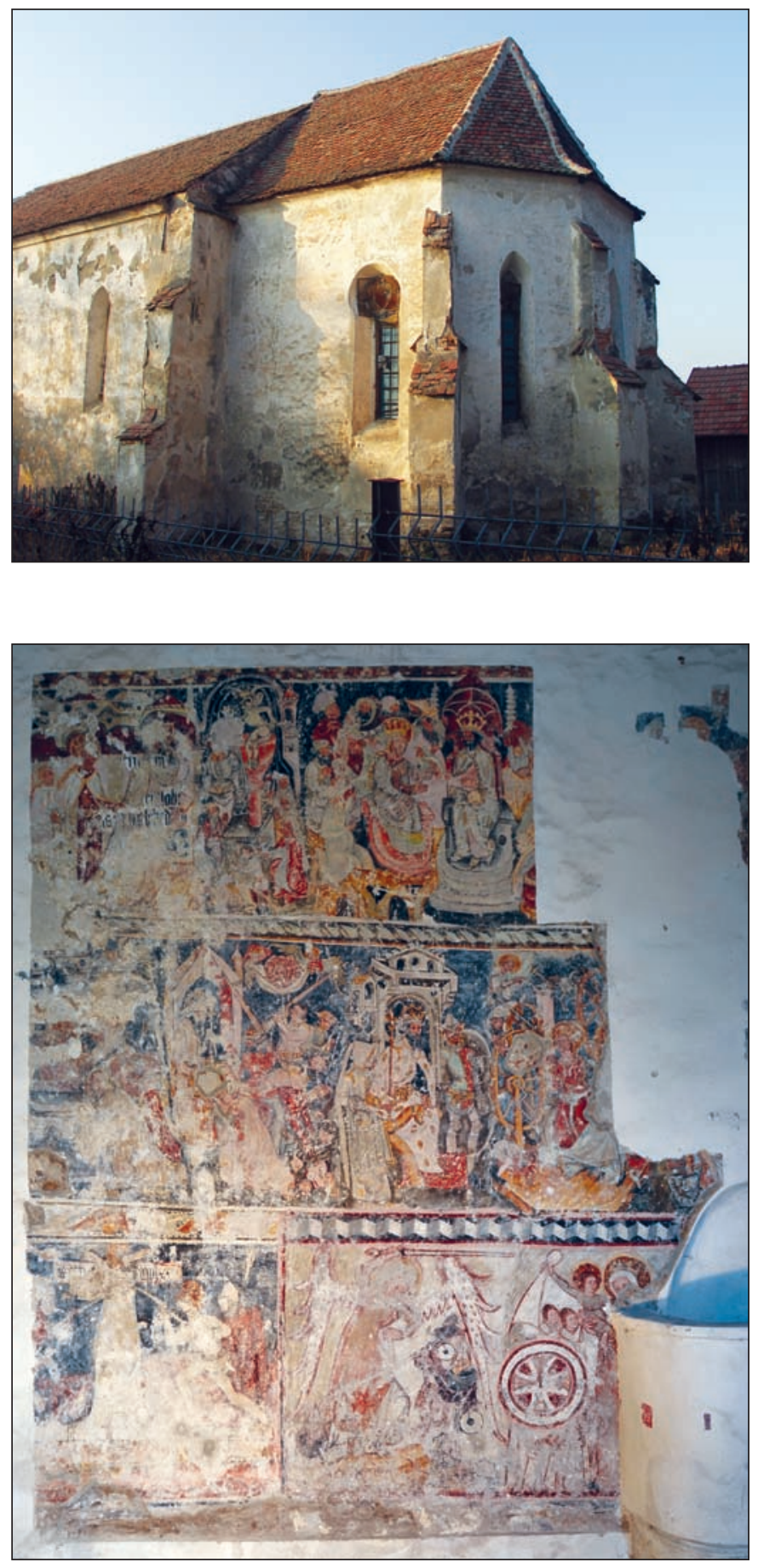


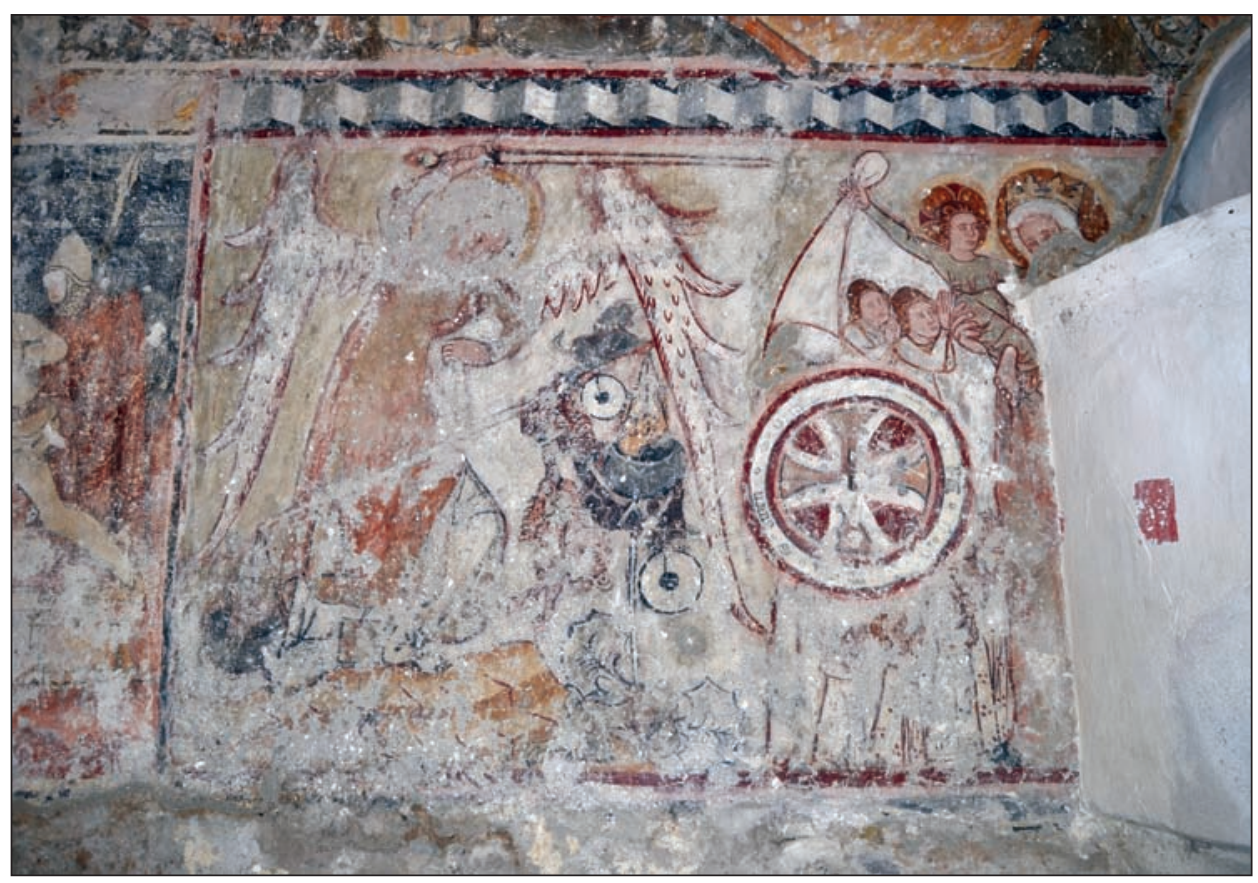

17

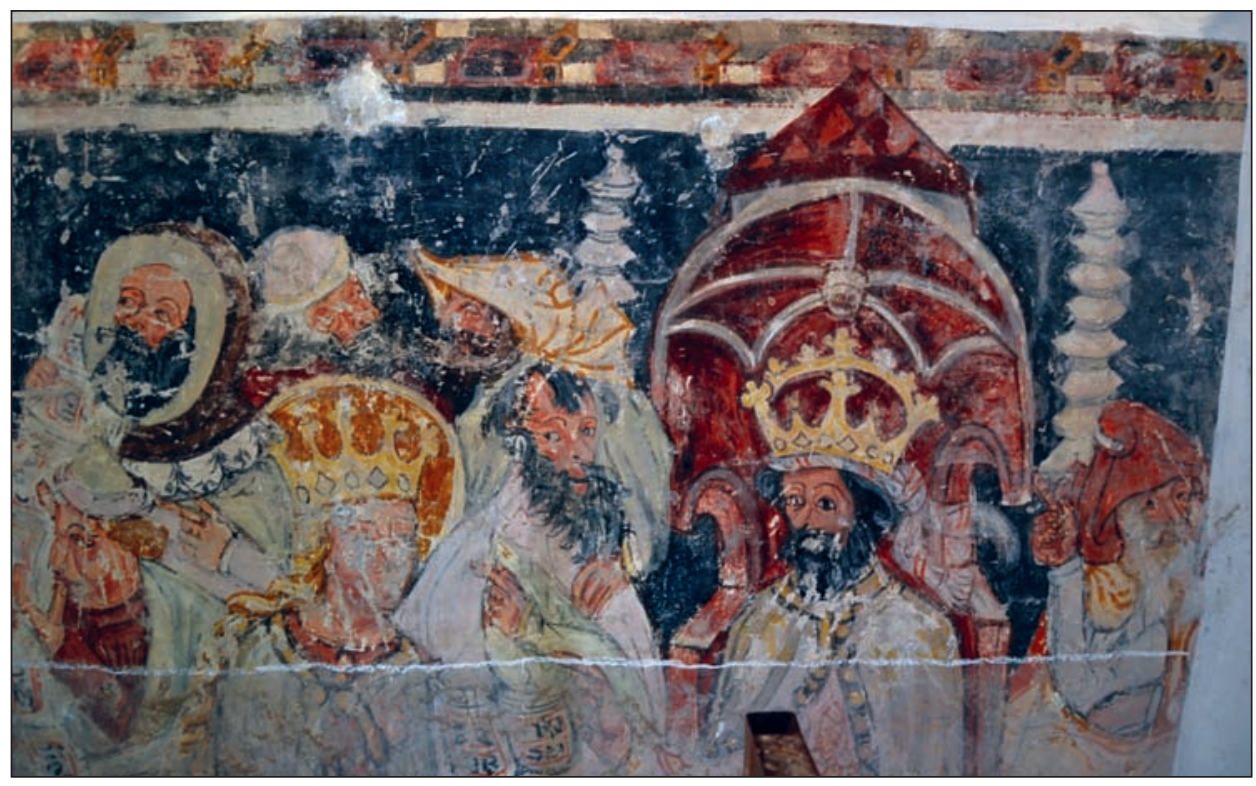


Kiss Ló r ánd

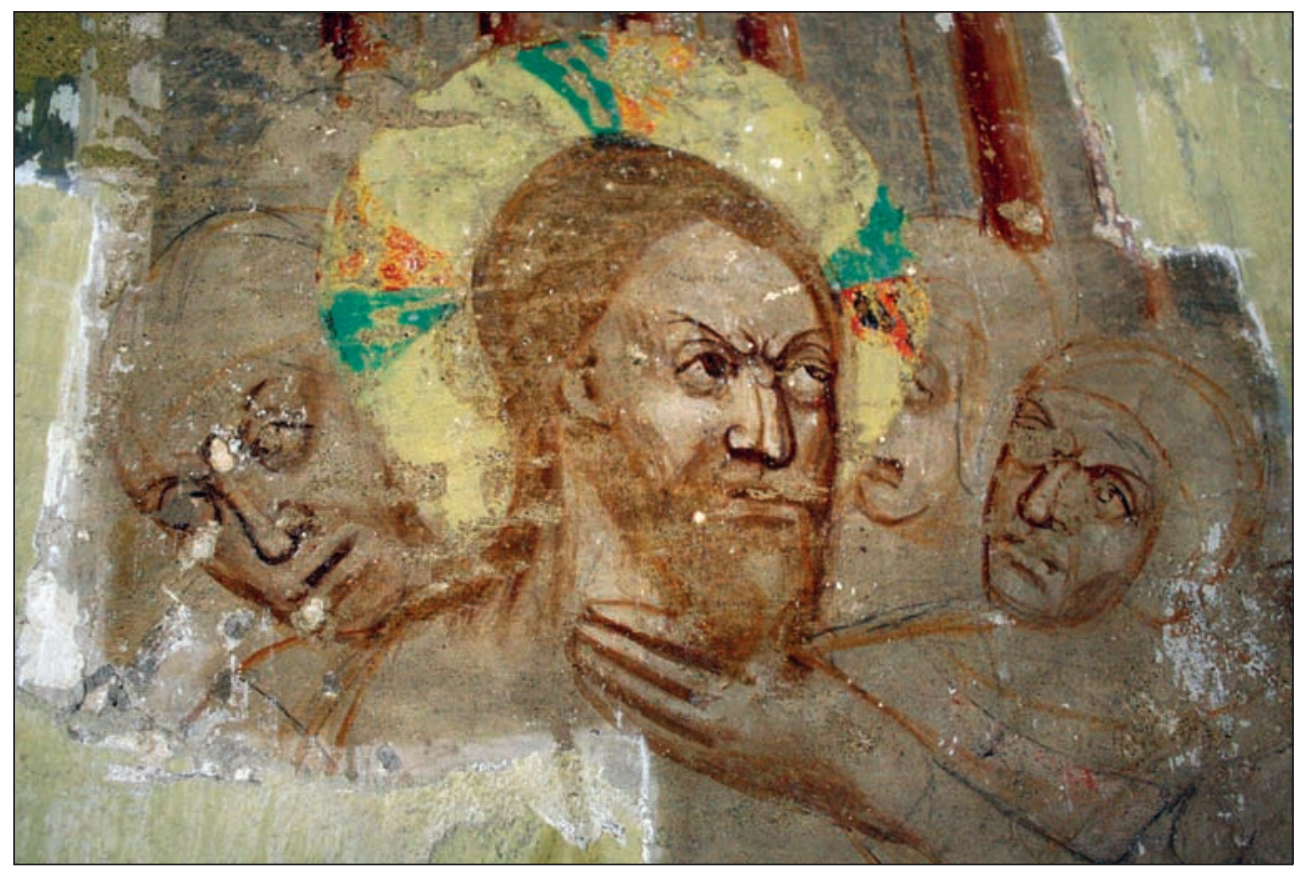

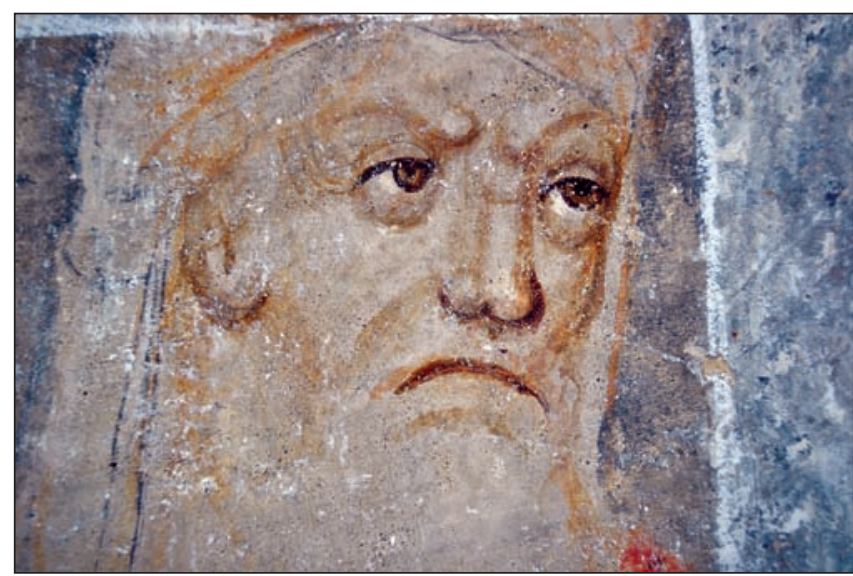

20

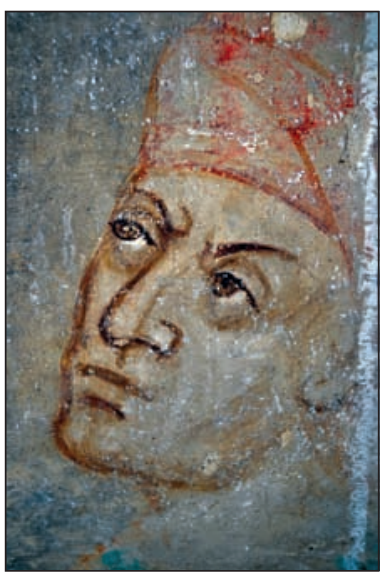

21 